\title{
Sain noyon xan kolostorvárosa
}

A sárgasüveges tanok terjedése és a mongol buddhizmus 17. században kezdődő virágkora után a Mongólia területén álló mintegy ezer kolostort és gyülekezetet a szocializmus kezdetén, 1937-38-ban lerombolták. A kolostorok többségéről nem maradt fenn történelmi adat. A cikk szerzője kutatótársával, Majer Zsuzsával idős szerzetesekkel készített interjúkat 2005-től, illetve Ulánbátor egykori és mai szentélyeinek történetét vizsgálta. Az általuk kidolgozott módszertan alapján 2007-ben országos kolostordokumentáló projekt indult, hogy a lerombolt és jelenleg múködő kolostorok történetét feltárja. ${ }^{1}$ Jelen cikk a 2007-es terepmunka, három idős szerzetes visszaemlékezése és napjainkban megjelent írott források alapján mutatja be az egyik jelentős mongol Gelukpa kolostor, Sain noyon xan kolostorának történetét, hogy magyar nyelven szemléltesse, mi maradt mára az egyes mongol kolostorok hagyományaiból, milyen forrásokra építkezhetünk a kolostorok történetének feltárásakor.

A mandzsu időszakban (1691-1911) a nyugati, ojrát területek kivételével a mai Mongólia csaknem egészét négy halha megye alkotta (aimag), melyek zászlókra oszlottak (xošū). A négy megye élén egy-egy halha főnemes állt. Egyikük volt Sain noyon xan. Az Ongi-folyó partján elterülő, 1666-ban alapult „lámafalut” elsősorban szerzetesek lakták, de világiak és kínai kereskedők is megtelepedtek körülötte, sőt 1906-ban a 13. dalai láma is megfordult itt. Alább, az idős szerzetesek szinte szóról szóra fordított visszaemlékezéseiből kirajzolódnak a kolostor szentélyei, 20. század eleji virágzó élete és a környező kisebb-nagyobb gyülekezetek. ${ }^{2}$ A kolostor helyén ma Öwörxangai

Részleteit lásd www.mongoliantemples.org.

2 Jelen cikk interjúinak nagy részét a szerző Majer Zsuzsával közösen készítette; az Uyanga járásbeli megfigyelések az Arts Council of Mongolia 2007-es kolostordokumentáló projektjének keretében közösen végzett háromhónapos kutatás eredményei. A szerző Sain noyon xan kolostorvárosa címú előadása 2009-ben az Orientalista Napon hangzott el. Jelen cikk a Bolyai János Kutatási Ösztöndíj támogatásával készültt. 
megye Uyanga járásközpontja áll; a kolostornak szinte nyoma sincs. A fél évszázados vallási elnyomás után az 1990-es rendszerváltáskor az egykori, addigra idős szerzetesek újjáépítették a kolostor egyik szentélyét, melynek a régi kolostor tibeti nevét adták (Gandancemplen, tib. dga'-ldan tshe-phelgling, 'örömteli, életet hosszabbító kolostor'). ${ }^{3}$ A cikk a kolostor 20. század eleji állapotáról, történetéról tudható adatokat közli, illetve a kolostorok történetéhez használható forrástípusokat, a mongol kolostorok általános jellemzőit szemlélteti.

\section{Az egykori Sain noyonī xošū és a mai Uyanga járás}

Öwörxangai megye atlasza szerint ${ }^{4}$ a Sain noyonī xošū ('a Jó nemes zászlóalja’) története 1655-ig nyúlik vissza, amikor Tüšēt xan alárendeltjei közül Tümenxan Sain noyon (1558-1640) fiának, Danjan szerzetesnek alárendelt népet és területet különített el ( $\left.\breve{s} a w^{\prime}\right)$, melyet Sain noyonī xošūnak neveztek el, s ezzel létrejött Tüšêt xan aimag nyolcadik zászlóalja. Ennek területét a mandzsu uralom alatt részekre szabdalták, így 1691-ben létrejött a kisebb területû Sain noyonī xošū, az Axai beisīn xošū és a Yost beilīn xošū, majd 1696-ban a Jorigt güngīn xošū, 1707-ben az Üijen wangīn xošū, 1737-ben az Erdene bandid xutagtīn šaw', majd 1826-ban az Erdene mergen noyon

3 Egyes mongol kolostorok angol nyelvű leírását lásd Majer 2012a, Majer 2012b, Majer 2013, Teleki 2012, www.mongoliantemples.org. Mivel Sain noyon xan kolostorvárosának virágzása, lerombolása és újjáélesztése méltán példázza Mongólia jelentős kolostorainak történetét, a cikknek nem célja állítások megfogalmazása és érvek felsorakoztatása; csupán egy mongol kolostor jellemzőit közli, hogy az egyes kolostorokról magyar nyelven hozzáférhetó adatokat gyarapítsa. A cikk viselhetné a „Kolostorváros az Ongi-folyó partján; kísérlet egy elpusztított buddhista közösség életének és környezetének rekonstrukciójára" címet, ám mivel a cikk leíró és nem feltáró jellegú, a Sain noyon xan kolostorvárosa (Sain noyonī xürē) címet kapta, melyen a kolostor széles körben ismert Mongóliában. A cikk számos mongol kifejezést tartalmaz, hogy a későbbiekben a szakirodalom feldolgozását lehetővé tegye. A tibeti eredetú mongol buddhista szavaknak a kutatás jelen állásában megfejtetlen eredetijét a cikkben kérdőjel (?) jelöli. A buddhista terminológiához, szertartások jellemzőihez lásd továbbá www.mongoliantemples.org, Majer 2009, Teleki 2012, Birtalan et al. 2015.

4 Ičinnorow et al. 2002: 275-276. 
xutagtīn šaw' terület. ${ }^{5}$ 1725-ben Sain noyon xan kiválva Tüšēet xan aimag igazgatása alól létrehozta a Sain noyon xan aimagot, így az ország területét felosztó halha megyék száma elérte a végleges négyet (Tüšēt xan aimag, Jasagt xan aimag, Secen xan aimag, Sain noyon xan aimag). Sain noyon xan aimag központi területe a Sain noyonī xošū maradt, mely az aimag területén

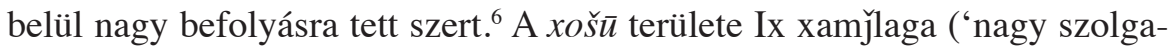
nép’), Baga xamǰlaga ('kis szolganép'), Gol sum ('fó járás'), Ix barūn sum ('nagy nyugati járás'), Baga barūn sum ('kis nyugati járás'), Jūin sum ('keleti járás') és Xondogo sum ${ }^{7}$ területi, szervezeti egységekből állt. A xoš̄u a mai Öwörxangai megye Uyanga, Bat-Ölz̄̄, Bogd, Barūnbayan-Ulān, Narīntēl, Xairxandulān járásának egész területét, valamint Gučin-us járás nyugati részét foglalta magában. Központja az Ongi-folyó partján álló „,kolostorváros” (xürê) ${ }^{8}$ a Sain noyon xanī xošū xürē volt, mely a mai Uyanga járásközpont helyén állt az 1937-es kolostorrombolásig. ${ }^{9}$ A kolostor 1923-ig a Sain noyon̄̄ xošū és a Sain noyon xan̄̄ aimag központja volt. ${ }^{10}$ Bár e kolostor a Sain noyon xanok székhelye volt, fontos megjegyezni hogy a megye ügyeiben nem a Sain noyon xan döntött egyedül: a döntéseket a Cecerlegben (mai Arxangai megye) évente összeülő megyegyúlés hozta (čūlgan). ${ }^{11}$

Öwörxangai megye atlasza részletesen szól Uyanga járásról (sum), mely 1931-ben jött létre 313936 hektárnyi területen, s melynek központja, Uyanga az egykori kolostor romjaira épült a fővárostól 492 km-re, Arwaixēr megyeközponttól 61 km-re. ${ }^{12}$ A Xangai-hegység előterében fekvő járás hegyekben,

5 Az egy-egy magas rangú szerzetes mellé rendelt területet és lakosait šaw'-nak ('tanítvány, alárendelt') nevezzük.

6 Az aimag területe 1725-ben 24 xošūból és 8 šaw' területből, azaz összesen 32 részből állt. 1918-ban a xošŭ területén 2200 család, azaz mintegy 10600 fó élt (Banjragč 1998: 83).

7 Xondogo: lóállás kifeszített kötele, melyhez a kötőféket kötik.

8 A xürē népes, általában körülkerítetlen kolostor neve, melynek közepén álltak a szentélyek, s a szerzetesi lakosság körülöttük lakott.

9 A kolostorváros egykori orvosi iskolájának koordinátája: É: 46²7.507’, K: 102¹7.469’ , 1990 m.

10 A közigazgatási területek nevei 1923-ban, majd 1931-ben változtak, így az egykori Sain noyon xan aimag (1725-1923) később Cecerleg Mandal ūl aimag lett (1923-1931), majd 1931ben létrejöttek területén a mai megyék: Öwörxangai aimag, Arxangai aimag és a többi.

11 Részletesen lásd Sonomdagwa 1961: 50, 55, 58.

12 Ičinnorow et al. 2002: 272-281.2001-ben lakossága 7649 fő volt, állatállománya ma 135000. 
vizekben, kulturális örökségben gazdag. ${ }^{13}$ Országszerte híres aranyáról,${ }^{14}$ ásványkincseiről, jaktejéről és sajátos díszítő elemeiről. Északon az Ongi-folyó, ${ }^{15}$ nyugaton a J̌argalant, az Urd Bōrölȳüüt és a Bat xān ūl vonulata, délen a Xan Xögšin-hegy határolja, melyen a régi oorhely, a Xarūlīn Šiwē owō áll. A mai járásközpontban alig emlékeztet valami az egykori kolostorra, melynek szentélyeit az 1930-as évek végén egytől egyig lerombolták.

\section{Sain noyon xan, T. Namnansüren (1878-1919), a kolostor utolsó híres nemese}

A Sain noyon xanokról szóló közreadott forrás kevés, a levéltári adatok kiadatlanok, a kérdezett szerzetesek Namnansürent 1919-ben bekövetkezett halála miatt már nem ismerték. ${ }^{16}$ Tögs-Očirīn Namnansüren (vagy Širindambīn Namnansüren) volt az utolsó híres Sain noyon xan, egyben Borjigin nemzetségbeli sarj, azaz Dzsingisz kán leszármazottja. Namnansüren Mongólia elsô miniszterelnökeként közismert (1912-1919). ${ }^{17}$ 1878-ban született Sain noyon xan, Tögs-Očir második fiaként. ${ }^{18}$ Apja 1896-ban bekövetkezett halála után lépett helyébe, majd 1897-ben alherceg (xošoi čin wan), a közigazgatási egységet irányító zászlósúr (xošū jaxirax jasag), a megye élén álló

13 Számos türk kori emlék (Ongīn türeg bičēs, Öwörxangai türeg bičēs, Türegīn tamgan xöšō, Ongīn golīn dursgal), régi temetkezési (On'tol'tīn xünnü bulš) és emlékhely, azaz xirgisūrr) xeregsǖr (Bitütīn dursgal, Jün J̌argalantīn am, Öndör xirgisür), a 12. századból Arslan kán egykori városának maradványa (Arslan xānī xotīn tūr' vagy Olon sümīn xöl), valamint Jün (e) rēt (Xunx taxix) találhatóak itt (Maidar 1970: 24).

14 Az uyangai aranybányákról Mette High végzett antropológiai kutatásokat.

15 A 435 km hosszú Ongīn gol a Xangai délnyugati vonulatából ered. Nevét az Ongi čulūról, az Uyanga járásközponttól 5 km-re északnyugatra, Güntīn garam nevú helyen álló 60x70 cm-es ongi ('szerszámon a nyelet befogadó lyuk, köpư’) formájú kőről kapta. Az Öwörxangai és Dundgow' területét átszelő, Ömnögow' megyei Ulān nūr-tóba ömlő folyó vízgyújtô területe $52920 \mathrm{~km}^{2}$. Partján egykor számos kolostor állt (Sain noyon xan̄̄ xürēe, Ongīn xural, Bragri lamīn xīd, Xutagt lamīn xīd, Xošū xīd stb.), melyeket 1937-38-ban leromboltak.

16 Veronica Veit egy 1795-ös forrás alapján szól a korai Sain noyon xanokról és rokonságukról (Veit 1990: 105-175).

17 Öwörxangai megye atlasza (Ičinnorow et al. 2002) és a T. Namnansüren születésének 120. évfordulójára 1998-ban rendezett ulánbátori konferencia 14 előadást tartalmazó kötete (Gombosüren - Dorj̃dagwa 1998) szintén számos fontos adatot közöl.

18 Lásd http://www.mongolinternet.com/famous/SainNoyonHanNamnansuren.htm. 
kán (aimgīn xan), végül a cecerlegi gyưlés elnöke lett (Cecerlegīn čūlgan̄̄ darga). ${ }^{19} \mathrm{Az}$ 1911-es függetlenedés egyik kulcsfigurája volt; ő is aláírta a cári Oroszországtól való segítségkérést. Az 1911-ben teokratikus uralkodóvá választott Bogd xāntól (1870-1924)20 zöld gyaloghintót (nogōn ǰ̄ūj), sárga ködmönt ( ̌̌ar xürem), narancssárga gyeplőt (ulbar šar ǰolō), bizalmasi (itgemjit eyetei) és uralkodó harcos (erx daičin) címet kapott, személye körüli minisztere (šadar said), 1912-ben miniszterelnöke lett (yerönxī said), s a Tümenxan nomun ejen címet kapta. Sok idôt töltött Urgában, a fővárosban, mely 1912-től a Nīslel xürē nevet viselte. 1913 októberében több magas rangú mongol államférfi kíséretében Szentpétervárra utazott, hogy Mongólia függetlenségét elismertesse. ${ }^{21}$ Miniszterelnökként 1913-ban középiskolát alapított a fővárosban, jogi kiadványokat írt, hetven iskolát alapított, és bevezette a drágakő vadzsra kitüntetést (erdene očir). Xujirbulanban katonai iskolát épített ( cergīn surgūl'), valamint Irkutszkba, Xyagtába és Ulan-Udéba küldött gyerekeket tanulni. Nevéhez fúződik a Šine tol' (1913) és a Nīslel xürēnī sonin (1915) újságok indítása. 1915-ben aláírta a híres xyagtai szerződést. $^{22}$

T. Namnansürent 1919-ben megmérgezték. Földi maradványait még abban az évben elvitték a fővárosból, és kolostorának külön szentélyében őrizték két évig. Végül a közeli Xan šarilīn nurūn, a Sain noyon xanok temetkezési helyén helyezték örök nyugalomra. Síremlékét (bunxan, tib. 'bum-khang) 1922-ig őrség felügyelte, ${ }^{23}$ majd 1925-ben Pyotr Kuzmič Kozlov (18631935) kutatócsoportja titkon feltárta. Namnansüren fia, Batsüx 1919-1921 között töltötte be Sain noyon xan aimag utolsó, 17. jasag noyoni tisztét.

19 Ičinnorow et al. 2002: 178-179.

20 Az újjászületố Bogd jawjandamba xutagt (tib. rje-btsun dam-pa) láncolat nyolcadik tagja.

21 Badarči - Dugarsüren 2000: 197. Namnansüren éves járadósága (pünlü) 2500 lan ezüst (möngö) volt (1 lan = 37,3 g). Főtanácsadója (jöwlöx said) Secen xan Nawānneren, helyettese (ded said) a belső-mongol Jirmīn čūlgan helytartó nemese (jasag noyon), ǰ̄n wan Gončigsüren volt. Lásd http://www.mongolinternet.com/famous/SainNoyonHanNamnansuren.htm.

22 Lásd http://www.mongolinternet.com/famous/SainNoyonHanNamnansuren.htm.

23 Ičinnorow et al. 2002: 225. 


\section{A kolostor szentélyei különböző forrásokban}

Sain noyon xan kolostorához a 20. század elején mintegy 30 szentély (süm dugan) tartozott. A szentélyek elhelyezkedéséról néhány fénykép, egy leírás, sőt három rajz is ismert, mely ritka a mongol kolostorok esetében. A hatalmas szentélyeknek, sztúpáknak ma csupán kőalapjai vehetők ki a rátelepült Uyanga járásközpont területén; lehetetlen megszámolni, hány szentély létezett. Az egykori kolostor kiterjedése 200x300 m lehetett. A szerzetesek egykori városukat Sain xanī xürē, Sain noyon xan̄̄ xürē, Sain noyonī xürē, Xan Xögšnī xürē, Uyangīn xürē néven említik, de Sain noyon xanī xošū xürē, Ongīn xürē ${ }^{24}$ és Gandancemplen/Gandansemplen (tib. dga'-ldan tshe-phelgling) néven is ismert. A kolostort Maidar és Rinčen jelöli egykori kolostorok helyét jelző térképén, ${ }^{25}$ illetve néhány forrás részletesen szól róla.

A városról kevés, 1923-ban Pyotr Kuzmič Kozlov által készített fénykép ismert, melyek közül egy a járásközpont mai kolostorában, a Gandancemplen xīd falán is látható. ${ }^{26}$ A kép délről, a Xan Xögšin ūl-hegyről készült, így jól látszanak az előtérben álló sztúpák, a magas tibeti és kínai típusú szentélyépületek és a körbekerített udvarok. ${ }^{27}$ Két másik fénykép a Sain noyon xan kolostor mauzóleumát, illetve egy nagy és két kisebb sztúpát mutat, melyek alatt át lehetett menni. ${ }^{28}$

Három rajz jelzi a szentélyek elhelyezkedését, több-kevesebb átfedéssel. ${ }^{29}$

\footnotetext{
Vö. Majer 2013.

25 Maidar 1970: 88, 678. bejegyzés: Uyanga sumīn Sain xanī xürē, alapítás éve: 1700 (Rinčen Maidar 1979: 38. térkép, 820).

26 E fekete-fehér felvételt 2004-ben adományozta a kolostornak Ragčāgīn Badamdamdin parlamenti képviselő. A kolostorról az ulánbátori Film- és Audiovizuális Archívum nem ôriz felvételt. A Mongol Tudományos Akadémia Fotótárában láthatók Kozlov által készített fényképek.

27 Érdekes, hogy jurták helyett inkább fa- vagy kőépületek látszanak, melyekben a város szerzetesei éltek.

28 Lásd http://mongoliantemples.org/index.php/en/component/domm/2028?view=oldtempleen.

29 Č. Gansüxnek, a Mongol Nemzeti Könyvtár tudományos munkatársának szíves közlése szerint az uyanga-i múzeum birtokában volt egy, a régi kolostorvárost ábrázoló régi rajz is.
} 
1. Az R. Lxangiw által 1991-ben készített rajzot a 2007-ben még épülő orvosi szentély vezetôje, G. Banjragč ôrzi. A kép címe Gandansemplen xīdīn büdīwwč jurag (Ongīn xürē), azaz A Gandansemplen kolostor, más néven Ongīn xürē vázlata. A képen látható, hogy a város szentélyépületei - mongol szokás szerint - délre néztek. Minden szentély körülkerített udvarban állt, melyek kapuja délre nyílt. A város előterében a szerzeteseket imára hívó emelvények (bürēn̄̄ šat), kisebb sztúpák (suwarga) és leborulásra szolgáló padok álltak. A sztúpák mögötti téren egykor a cam (tib. 'chams) vallási táncot mutatták be. Az út délről a főszentély felé vezetett (Cogčin dugan vagy Čogčin dugan, tib. tshogs-chen 'du-khang), mely kétszintes, tibeti stílusú épület volt, déli és nyugati udvarbejárattal. A főszentély előtt a Déli kapuszentély állt (Goloi dugan, tib. sgo lho’i ‘du-khang), balján az orvosi iskola déli, keleti és nyugati kapus udvarával (Mamba dacan, tib. sman-pa grwa-tshang), mely elótt a Három terület szentélye kapott helyet (Xansüm dugan, tib. khams gsum 'du-khang). Az orvosi iskola bal oldalán a hatalmas Nyugati szentély helyezkedett el (Barūn dugan). A fószentély délkeleti sarkán állt a szerzeteseket imára hívó emelvény, attól keletre pedig a nagyméretú Keleti szentély (Jün dugan). A főszentély északnyugati oldalán volt a Kālacakra iskola (Düinxor, tib. dus-'khor), nyugati oldalán három sztúpával. A főszentélytől északnyugatra álltak a Goloi lagan (tib. sgo lho'i lha-khang) és a Gimplen lagan jurtái (tib. dge'phel-gling lha-khang), majd a Gimplen szentély udvara (tib. dge-"phelgling ‘du-khang). A fooszentély északkeleti oldalán a tantraiskola (J̌̈ü, tib. rgyud) helyezkedett el, a főszentélytől északkeletre pedig a palotaszentély (Lawiran dugan vagy Lawran dugan, tib. bla-brang), jobbján a fokozatos út iskolával (Lamiram süm vagy Lamrim süm, tib. lam-rim).

A főszentély mögött balról jobbra a Gün-ā yadamīn süm (tib. sku lnga yi-dam $)^{30}$ udvara állt két egyszintes szentélyépülettel, majd a tibeti stílusú kétszintes filozófiai iskola (Čoir dugan, tib. chos-grwa), Mahākāla egyszintes szentélye (Maxgal vagy Gombo, tib. mgon-po),

30 Mongol nevén Tawān xan (tib. sku lnga rgyal-po), azaz az öt királyból álló istenségcsoport. Tagjai: tib. 'phrin-las rgyal-po, chos-skyong, dgra-lha, klu-dbang, tha-'og chos-rgyal-po. 
végül Yama egyszintes szentélyének udvara (Damjin, tib. dam-can), melynek keleten volt a bejárata. Ezen épületek mögött volt a nyomda udvara (barxan, tib. par-khang) három épülettel. Ettől keletre az Ezer buddha vagy az Ezerhangú szentély ${ }^{31}$ udvara állt (Myangan burxanī süm vagy Myangan dūtīn süm), három bejárattal. Ezek mögött egy sorban balról jobbra a J̌ančüwlin dugan (vagy J̌ančiwlin, tib. byangchub-gling 'du-khang) és a Dašdandarlin dugan (tib. bkra-shis bstandar-gling 'du-khang) ${ }^{32}$ egyszintes szentélyei álltak, valamint a Dulam Namjirīn süm (tib. sgrol-ma rnal-'byor?) szentély lapos, hosszúkás épületének déli, keleti és nyugati kapus udvara, valamint ettől kissé hátrébb a Nalsan dugan (tib. ?) tibeti stílusú épülete. Ezek mögött, a Sain noyon xan palotájához vezető út nyugati és keleti oldalán egymás mellett, két külön udvarban a helyi megtestesülés szentélye (Xuwilgān bagšīn süm) és a tibeti fóapát szentélye állt (Gačin bagšīn süm, tib. mkhan-chen), akik a kolostor szerzeteseinek legfontosabb mesterei voltak. A helyi megtestesülés, újjászületés szentélyétől északkeletre kapott helyet a vörös tanvédő, Begce egyszintes szentélye (Begj, J̌amsran, tib. lcam-sring), az Ulān saxiusnī süm.

Sain noyon xan palotaegyüttese a város északi részén állt. A magas kerítésú udvarra a déli kapun, illetve a mellette lévő kisebb kapun lehetett belépni. Az udvar északnyugati részén állt a kán kétszintes palotája (semčin, tib. gzims-khang), északkeleti részén a gazdagságot hozó Kubera vagy Vaiśravaṇa egyszintes szentélye [Namsrain süm, tib. rnam-(thos)-sras], valamint a délkeleti sarokban a kegytárgyat őrző két keleti, díszes jurtaszentély (Jün šütēn), a délnyugati sarokban pedig a kegytárgyat őrző két nyugati, díszes jurtaszentély (Barūn šütēn). A palota mögött, külön udvarban állt az ereklyetorony (sztúpa) egyszintes szentélye (Suwargan dugan), valamint leghátul, közös talapzaton hat sztúpa. A várost északon az Ongi-folyó határolta.

31 A név azonosítása további kutatásokat igényel.

32 Egyéb torzult alakjai Dondirlan, Dašdirlan. 
2. A Dājaw által közölt rajzon ${ }^{33}$ a szentélyek elhelyezkedése jobbára megegyezik a fent leírtakkal, ám nevük néhány esetben eltér: Nalsan dugan szerepel Nanslan helyett; az Ezer buddha szentélyét Jūnak írja (tib. jo-bo), mely Šākyamuni Buddha ábrázolására utal. Dājaw szerint a város közepén álló főszentélyhez széles út vezetett. ${ }^{34}$ E szentély 64 tartóoszlopú, kékesszürke téglából (xöx tōsgo) készült hatalmas épület volt. Északnyugati oldalán a Dandarlin aimag szentélye, a tantraiskola, a filozófiai iskola, valamint a Kālacakra iskola állt, északkeleti oldalán pedig a fokozatos út iskola. Dājaw leírásából részleteket is megtudhatunk egyes szentélyekről: a főszentélytől délkeletre a világoskék zománccal (pālan) bevont cseréptetejú (wār) Keleti szentély (Jün dugan), délnyugatra pedig a zöld zománccal bevont cseréptetejú Nyugati szentély (Barūn dugan), valamint a világoskék cseréptetejú Goloi szentély és Gemplen aimag szentélye állt. Sain noyon xan igazgatási központját a kolostor északkeleti részén álló bekerített palota és szentélyek jelentették. Dājaw szerint ez a palota (semčin), valamint a dalai láma palotája is kétszintes volt. Körülötte különböző buddhák szentélyei, mögötte pedig a sztúpaszentély vagy ereklyeszentély állt, melyben a legenda szerint Sain noyon xan, Namxaidagwa (1883-1896) 35 ereklyéit órizték egy márvány belsejú mauzóleumban (jos bunxan). Dājaw szerint emögött állt a 13 sztúpa együttese, melyet más forrás nem erősít meg. Hozzáteszi, hogy Sain noyon xan mestereket gyújtött maga köré, s kézmúipart létesített a városban (gar üildwerlel): innen ered a ma országszerte híres uyanga-i jurtatartóoszlop-díszítés is.

3. A megye atlasza is közöl képrészletet a régi városról, és leírja a szentélyek elhelyezkedését. ${ }^{36} \mathrm{~A}$ leírás szerint Sain noyon xan aimag és Sain noyonī xošū kormányzati hivatalának (Tamgīn gajar) kerítéssel körülvett együttesét Sain noyon kormánypalotája (törīn örgō), nyári palotája vagy hálóterme (noyonī semčin, serīn semčin), Congkhapa és két fő

33 Dājaw 2006: 184, 166. kép; 266. 254. kép.

34 Dājaw 2006: 183.

35 Namxaidagwáról más forrás nem tesz említést, ám halálának időpontja Sain noyon xan TögsOčir halálának időpontjával azonos.

36 Ičinnorow et al. 2002: 227-228, lásd ugyanezt Cedendamba et al. 2009: 543. 
tanítványának szentélye (Yawsrai burxan̄̄ süm, tib. yab-sras), a Nyugati kegytárgy-szentély, a Keleti kegytárgy-szentély, az Ereklyeszentély, valamint a Dalai láma szentélye és Kubera szentélye, az áldozati jurtaszentély (taxilīn örgö), Sain noyon xan feleségének, azaz a kánasszonynak a jurtaszentélye (xatnī örgö), a tüzhely vagy konyha (gal golomt), a barna jurtapalota (bor örgö) és további szebbnél szebb szentélyek és jurták alkották. A kormánypalota jobb oldalán a Bosgo čulū ('küszöb kő') állt, melyre az idegenek, a vendégek, a versenylovakat nevelő csikósok, a birkózók és a zarándokok áldozati selyemkendőket ( $x a d a g$, tib. kha-btags) és füstölőt helyeztek áldozatul. A kormánypalota mögött hat sztúpa állt, előtte hatalmas imamalom, melyet négy-hat ember tudott forgatni.

A 2007-es kolostordokumentálás után megjelent mongol nyelvű könyv szintén összegzi a szentélyeket, megállapítva, hogy a kolostorvárosnak mintegy harminc szentélye volt: a kán kormánypalotája, hálótermei, Kubera szentélye, a keleti és nyugati kegytárgy szentélye, az ereklyeszentély, az újjászületés szentélye, a tibeti fóapát szentélye, Begce szentélye, a J̌ančiwlin, Dandarlin, Dulamnamǰir, az ezerhangú szentély (Myangan dūt), a Nalsan, a nyomda, Tawan xan, a filozófiai iskola, Mahākāla szentélye, Yama szentélye, a Gemplin, Kālacakra szentélye, a Goloi lagan, a főszentély, a tantraiskola, a fokozatos út iskola, a nyugati iskola, az orvosi iskola, a Xansüm szentély, a keleti iskola, a cam tánc tere és sztúpák tartoztak hozzá. ${ }^{37}$

E leírásokból több-kevesebb részletet tudunk meg a kolostor szentélyeiról és Sain noyon xan palotájáról. A kormányzati hivatal igazgatta a kolostor, a xošū és az aimag gazdasági ügyeit, adózását, míg a Sain noyon xan palotáját alkotó szentélyekből következtethetünk arra, hogy milyen lehetett a négy halha kán lakhelye, udvartartása. Jurtáikon és fából készült palotájukon kívül áldozatbemutató szentélyek, áldozati tárgyak szentélyeit találjuk itt. A gal golomt valószínúleg nem a konyhára utal, hanem a kánok hagyományára, „túzhelyére,” a túz őrzésére, mely a mongol kultúrában szimbolikus jelentőséggel bír. ${ }^{38}$

37 Cedendamba et al. 2009: 543.

38 Vö. Urgában, az Awtai sain xanī örgöben őrizték Awtai sain xannak (1554-1588), az Erdene Jū kolostor alapítójának tüzét. 


\section{A 13. dalai láma látogatása}

A dalai láma (tib. thub-bstan rgya-mtsho, 1876-1933) 1904-ben érkezett Urgába, ahol magas rangú mongol szerzetesekkel és előljárókkal is megismerkedett. Hazafelé vezető vidéki útja során a Xand čin wangīn xürēben (ma Bulgan megye), a Jaya gegēn̄̄ xürēben (Arxangai megye), valamint a Sain noyonī xürēben időzött. ${ }^{39}$ A Sain noyonī xürēben, azaz a Gandancenpillin kolostorban való tartózkodásakor szerezte a Gandanpuncaglin kolostor főszentélyének és filozófiai iskolájának rendszabályát (ǰayig, tib. bca'-yig), a tűz-kígyó évének (1906) első őszi havában a Sain noyon xan, a kolostor ded és dā lámái és nemesek kívánságára. ${ }^{40}$ Tartózkodásának emlékét őrzi a nevét viselő palota vagy szentély. A dalai láma látogatása rendkívül jelentős esemény lehetett a kolostor szerzetesei számára, mivel a mongol buddhisták mélyen tisztelték.

\section{Szerzetesek emlékei az 1920-as, 1930-as évekről}

Míg 1990-ben, a rendszerváltáskor az egykori kolostor szerzetesei közül minden élő, mintegy 40 szerzetes részt vett az új szentély megnyitóján, 2007-re mindössze hárman-négyen maradtak: M. Menddawā, C. Cerendorǰ és Č. J̌amiyānsenge. E szerzetesek az 1910-es, 1920-as években születtek. Visszaemlékezéseik a kolostorrombolás előtti szerzetesi élet fontos forrásai, továbbá szemléltetik, mire emlékeztek kilencven évesen a romboláskor tizen-, huszonéves szerzetesek.

1. M. Menddawā az interjúk készítésekor az ulánbátori Gandantegčenlin kolostor szerzetesi közösségéhez tartozott. 1920-ban született, hat-hét éves korától 1936-ig, azaz 17 éves koráig volt a Sain noyonī xürē szerzetese. Közlése szerint a több mint 1000 szerzetest számláló kolostor az Ongi-folyó partján, Cecen dayan nevú helyen állt. Mivel a város a

39 Batbayar-Gombosüren 2009: 36-37.

40 Lxam - Yerölt 2011: 29-31. 
Sain noyonok székhelye volt, története 200-300 évre nyúlik vissza. Az utolsó Sain noyon meghalt, mielőtt Menddawā szerzetes lett (T. Namnansüren 1919-ig élt). A város híres újjászületése (Xuwilgān bagš) Düwčin Sodnom (tib.grub-chen bsod-nams) Menddawāés sok más szerzetes mestere volt. A kolostorhoz számos szentély tartozott, mint például a Golīn dacan ('központi kolostoriskola'), a filozófiai iskola (Čoir), a tantraiskola (J̌üd), a Kālacakra iskola (Düinxor), az orvosi iskola (Mamba), a Nyugati iskola (Barūn dacan), a Keleti iskola (Jǖn dacan), a fokozatos út iskola (Lamrim), a J̌ančüwlin dacan, a J̌impellin (?) dacan, a Nanslan, a Nügnei (tib. smyung-gnas, 'böjt'), a Dandillan/Dondowlin, a Xamsüm, a Myangan burxan, a Gempellin és az újjászületés szentélye (Xuwilgān bagš). ${ }^{41}$ Majd' minden szentélyépület téglából (tōsgo, tōpü vagy toip $\bar{u})^{42}$ és agyagból épült ( ̌̌awar), csupán négy-öt lehetett fából. A szentélyek többnyire kétszintesek voltak, a második szinten Buddha áldozóhelyével. A főszentély (Golīn dacan) kétszintes, hatalmas épület volt, míg a szentélyek jobbára tibeti stílusban épült fehér, négyszögletes épületek voltak. Menddawā szerint a kolostornak nem volt külön nyomdája, de a szerzetesek otthon nyomtattak vagy másoltak könyveket. A Tibetból érkezett fóapát (gačin lam, tib. mkhan-chen) a város nagy tekintélyú mestere volt, és saját gazdasági hivatallal rendelkezett (̌̌as, tib. spyi-sa), illetve minden egyes szentélynek volt saját gazdasági hivatala. ${ }^{43}$ Maga Menddawā szerzetes a J̌ančüwlin szentélyhez tartozott, melynek száz szerzetese volt. A filozófiai iskola a Szera segédkönyvét követte (Ser ǰewcün gegēní igčā, tib. yig-cha); fő tanvédője Śrīdevī (Lxam, tib. dpal-ldan lha-mo). Congkhapa ábrázolását szintén tisztelték. A főszentély oltárát a tíz haragvó istenség (arwan xangal) szobrai díszítették. ${ }^{44}$

$41 \quad$ Menddawā szerzetes az összes nagyobb szentélyt a dacan (tib. grwa-tshang, 'kolostoriskola') névvel illeti.

42 A tōpūi vagy toip $\bar{u}$ kínai eredetú jövevényszó, melynek eredetét nem sikerült rekonstruálni.

43 Mongóliában a szentek, újjászületések és egyéb magas rangú szerzetesek kincstárral (san), a szentélyek gazdasági egységekkel (jas) rendelkeztek. A gazdasági egységekbe befolyt adományokból biztosították egy-egy szentély múködését, szerzeteseinek étkeztetését, a szentélyépület felújítását. Kincstárról a város kapcsán senki nem tett említést, gazdasági egység sok szentélyhez tartozott.

44 A tíz haragvó istenség: Gombo, Gongor, Namsrai, Šalš, Lxam, Jigjid, Čoiǰō, J̌amsran, Očirwān', Camba. 
A város nem volt körülkerítve, ám négy oldalán egy-egy sztúpa állt, valamint északon egy nagy sztúpaegyüttes, a J̌ügdernamjil sztúpa (tib. gtsug-tor rnam-rgyal, szkr. Uṣnịṣavījayā). Szerzetesnők nem tartoztak a kolostorhoz. ${ }^{45} \operatorname{Jod}$ (tib. gcod) tantrikus gyakorló joč mesterek nem éltek a városban, bár vidéken volt néhány. Szegény családok éltek a város körül, és voltak hatalmas kínai boltok is ( $p \bar{u} s$, kínai: $p u z i$ 铺子), ahol selymet, lisztet és egyéb árucikkeket árultak. Pénz nem volt használatban akkortájt, ezért állati eredetú termékeket (gyapjú, nemez, lószőrkötél stb.) vagy téglateát adtak egy-egy „luxuscikkért” cserébe. Hívek gyakran jártak a kolostorba, adományul juhot, kecskét vagy más élőállatot, tejterméket hozva. Cam táncot kétszer tartottak évente. ${ }^{46}$ A nyári táncra nyár utolsó havának 7. napján került sor. Ebben mintegy száz szerzetes vett részt, a tíz haragvó istenséget, a vallástámogató Xašin xant (tib. he-shang rgyal-po), 20-30 feketekalapos táncost (šanag, tib. zhwa-nag) és egyéb alakokat megjelenítve. ${ }^{47} \mathrm{~A}$ tánc másnapján, 8-án, az eljövendő buddha, Maitreya szobrát és a Kandzsúr köteteit hordozták körbe a kolostor körül (Maidar ergex, Ganjūur ergex). A nyári elvonulás (yar xailen, tib. dbyar khas-len) nyáron, 60-100 szerzetes részvételével zajlott a főszentélyben. A filozófiára szakosodott szentélyekben sor került domīn damjā (tib. sdom-pa'i dam-bca') és gawjīn damj̄a (tib. dka' bcu'i dam-bca') filozófiai vizsgákra, míg a tantrikus tanulmányok iskolájában agrambīn damj̄a à vizsgákat tartottak (tib. sngags-rams-pa'i dam-bca'). Sok orvostudós volt (māramba, tib. sman-rams-pa), de Menddawā emlékei szerint māramba vizsgát nem lehetett tenni a kolostorban. A tantrikus buddhizmusra jellemző sor áldozati gúlát (tib. zor) évente kétszer égettek. A téli cam tánc ugyanolyan volt, mint a nyári. ${ }^{48}$ Ami a havi szertartásokat illeti, Manal (tib. sman-bla, szkr. Bhaișajyaguru) szertartást minden holdhónap 8. napján tartottak az Orvos buddha tiszteletére,

\footnotetext{
Mongóliában a női szerzetesek hagyománya nem létezett.

A cam tánc részleteit lásd Majer - Teleki 2014.

Részletesen lásd Majer - Teleki 2014.

48 A téli táncban kizárólag a fekete kalapos táncosok (šanag) szoktak részt venni, ezért e kijelentés további kutatást igényel.
} 
a Guhyasamāja tantrát (Sanduin y̌üd, tib. gsang-'dus-kyi rgyud) 15én olvasták, a haragvó istenségek tiszteletére rendezett Saxius szertartás 29-én volt, gyónást (soy̌in, tib. so-sbyong) és Naidan (tib. gnasbrtan) szertartást az arhatok tiszteletére 30-án tartottak. ${ }^{49}$ Számos rangos szerzetes tartozott a kolostorhoz, így corǰ (tib. chos-rje, 'a Tan ura') és lowon is (tib. slob-dpon, 'tanár'). ${ }^{50} \mathrm{~A}$ város szerzetesei a közeli Xan Xögšin-hegynek mutattak be áldozatot. A kolostor múködését 1937-ben állították le. Ekkor az újjászülető Xuwilgān lamot is elfogták.

2. C. Cerendorǰ szerzetes 2007-ben Uyanga járásban élt. 1918-ban született, kilenc évesen lett szerzetes. A kolostor (Uyangīn xürē néven említi) Nyugati ,iskolájának” szerzetese volt (Barūn dacan), ${ }^{51}$ ahová a xošū nyugati részéról érkezett szerzetesek tartoztak. A városban számos szentély állt, így a Cogčin (főszentély), a J̌ančüwlin, a Čoir (filozófiai iskora), a Düinxor (Kālacakra szentély), a Dandarlin, a Golīn Nogōn dugan ('zöld főszentély'), a Jüud (tantraiskola), a Mamba (orvosi iskola) és a többi. Közlése szerint mintegy 3000 szerzetes élt a kolostorban, és körülbelül 1000 szerzetes tartozott csak a Nyugati dacanhoz. A szentélyek kínai téglából (toipūi) épültek, felsô részük fából, szögek nélkül készült. Tetejük zöldre volt festve. A Nyugati dacant számos szobor és kép díszítette, mint például a tíz tanvédő és a 21 Tārā szobra. A Nyugati dacan fó tanvédője a vörös tanvédő, J̌amsran volt. A Nyugati dacanhoz egy elóénekes (unzad, tib. dbu$m d z a d)$, nyolc-kilenc jó hangú szerzetes, valamint egy rendfelügyelő tartozott (gesgüi, tib. dge-bskyos). ${ }^{52}$ A tíz tanvédő rituáléit tartották itt, továbbá Tārā (Dar' ex, tib. sgrol-ma) és Yama (Čoǐ̌il, tib. chos-rgyal) tiszteletére rendeztek szertartásokat. Cerendorǰ szerzetes maga a filozófiai iskolához (Čoir) is tartozott, ahol gyógyító szertartásokat és

49 Ez megegyezik a mai sárgasüveges szentélyek havi ünnepeivel.

50 Részletesen lásd Birtalan et al. 2015, www.mongoliantemples.org.

51 A dacan elsősorban kolostoriskolát jelent (tib. grwa-tshang), jelen esetben valószínúleg hatalmas, vagyonos szentélyt.

52 Egy-egy szentély szerzeteseinek számától függően egy-két eloénekes, két vagy négy jó hangú szerzetes és egy-két rendfelügyelő tartozhatott hozzá. 
jövendômondást is tartottak.$^{53}$ Ebben az iskolában Tārāt tisztelték, de nem emlékszik, hogy melyik segédkönyvet tanulmányozták. A városban voltak filozófiai vizsgát tett rawǰambāk (tib. rab-'byams-pa) és számos gawj. Tibetből egy nagykövet, a gačin láma jött a városba. A város szerzetesek által lakott részén mintegy 30 nagy szentély állt. Egy sztúpa állt középen, illetve voltak egyéb sztúpák is. A téglaégető $(b \bar{a} y \bar{u})$ északon volt, ahol a kínaiak éltek, akik téglával és árucikkekkel látták el a kolostort. C. Cerendorǰ szerint voltak imamalmok, illetve egy gyönyörú, díszes arany tankerék két gazellával, valamint Lxagan ${ }^{54}$ és Arany Kandzsúr (Altan Ganjūr) tartozott a kolostorhoz. A szerzetesek bekerített udvarokban éltek, de a kolostoron belül nem voltak aimag kerületek. ${ }^{55}$ Minden szentélynek volt gazdasági hivatala, nyájai és csordái. A Maitreya körmenetet az utolsó nyári hónap 8. napján rendezték az eljövendő Buddha tiszteletére, és a cam tánc is akkor volt. ${ }^{56} \mathrm{~A}$ sor áldozati gúlát 29-én égették. ${ }^{57} \mathrm{~A}$ cam táncban számos istenség testet öltött, így például a tíz haragvó (Lxam, Maxgal, Ulān saxius stb.), a bikafejú istenség (azaz Čoijill) és bársonykalapos táncosok (xilen malgaitai) [vagy feketekalapos táncosok (̌̌anag, tib. zhwa-nag)]. A Kandzsúr köteteit majdnem minden évben tevékre málházva körbehordozták a kolostor körül. A Maitreya körmenet után az elvonulást (xailen) a Čoir szentélyben (vagy a Cogčinban) tartották ötven-száz szerzetes részvételével. Sain noyon xan Namnansüren meghalt (1919-ben), mielőtt Cerendorǰ szerzetes a kolostorba került volna. Maradványait a Šarilīn šagnai nevú helyen helyezték el. Voltak szerzetesek, akik apát (xamba, tib. mkhan-po), lowon, corǰranggal rendelkeztek, mint például a Cogčin lowon, a főszentély tanára. A Čoir, a Cogčin és más szentélyekhez apátok (xamba lam) és vezetôk (tergün) tartoztak, akik sárga, szögletes, szalagos kalpagot viseltek (owōdoi).

53 A čoir valójában a filozófiai oktatás helye volt.

54 A szó jelentésének megfejtése további kutatást igényel.

55 A kolostorok körül éló szerzeteseket itt szentélyeik alapján oszthatták fel.

56 A Maitreya körmenetról részletesebben lásd Majer 2009, Teleki 2012.

57 A holdújév végének sor szertartására vonatkozhat. 
A dā lam és két demč hivatalnok ügyelt a kolostor vagyonára és gazdaságára. A filozófiai szentélyben voltak dom osztályok, és le lehetett tenni a domīn damj̄a filozófiai vizsgát. Cerendorǰ maga nem tett vizsgát. A Cogčin főszentély volt a legrégebbi szentély; tibeti stílusban épült téglából. A kolostor területén állt egy nyomda. Az egyik szentély ezer buddha-szobornak adott otthont (Myangan burxanī süm). A szerzetesek két közeli hegynek, a Xan Xögšin-hegynek és a Bayan-hegynek mutattak be áldozatot. Cerendorǰ szerint nem voltak szerzetesnők, és joč tantrikus mesterekre sem emlékszik. 1937-ben lerombolták a kolostort, „o maga 16 évesen lett világi (1936-ban). Vidékre ment, majd hat évet töltött a katonaságnál. 1990-ben a lerombolt kolostor helyén egy szentélyt újjáépítettek, hogy a kolostor hagyományát felélesszék. 34-35 egykori szerzetes gyúlt össze akkortájt, akik közül Cerendorj̆ szerint mindössze három vagy négy élt 2007-ben: (Yagān) Dašdorǰ ${ }^{58}$ Jamiyānsenge, valamint annak testvére, Menddawā. 2007-ben Cerendorǰ szerzetes a várostól mintegy tíz kilométerre lakott, egészségügyi okok miatt nem tudta a szertartásokat rendszeresen látogatni.

3. Č. Jamiyānsenge szerzetes 2007-ben Narīntēl járásban élt. 1919-ben született, a juh évében. Hatéves korától 15-16 éves koráig (19251935/36) élt a kolostorban, amelyet hol Uyangīn, hol Xögšin xīd néven emlegetett. Öccséhez, Menddawāhoz hasonlóan ő is a J̌ančüwlin szentélyhez tartozott, melynek fő tanvédője Mahākāla voltt, ${ }^{59} \mathrm{~s}$ ahol mindennap tartottak szertartásokat a kolostor többi szentélyéhez hasonlóan. Voltak évszakonkénti szertartások, mint például a tíz haragvó tiszteletére rendezett rítusok, illetve a himnuszok és imák szertartása (Molom vagy Yeröl, tib. smon-lam). Elmondása szerint mintegy 2000 szerzetes élt a kolostorban. A J̌ančüwlin szentély faépület volt, míg más épületek fóként téglából épültek (tōsgo). A Golīn dacan mellett a Barūn dacan és a Jün dacan volt a legnagyobb. A szentélyek tibeti

58 A 65 éves Dašdorjot a kutatás során megtaláltuk Narīntēl járásban, ő azonban nem volt régen szerzetes.

59 Menddawā szerzetes szerint Śrīdevī volt a fő tanvédő. 
stílusban épültek. ${ }^{60}$ A kolostorban élő gačin lam egy híres tibeti szerzetes volt. Voltak apátok, mint például a filozófiai iskola apátja (Čoir xam$b a$ ), vagy a főszentély fóapátja (Cogčin töw xamba). A kolostoriskolákhoz mesterek, tanárok (dacan lowon) tartoztak, illetve minden egyes szentélyben voltak rendfelügyelők és elóénekesek. Cam táncot évente kétszer tartottak. A Maitreya és a Kandzsúr körmenetet együtt tartották az utolsó nyári hónap 8 . napján, a cam táncot pedig a 9. napon. ${ }^{61}$ A táncban a tíz haragvó istenség figurája jelent meg. Télen is tartottak cam táncot, az újév 16. napján. ${ }^{62}$ Sor áldozati gúlát is égettek. Nem emlékszik, hogy lettek volna joč mesterek a kolostorban; ók inkább vidéken éltek. Jamiyānsenge szerzetes szerint a kolostor alapításakor a mandzsu császár elrendelte, hogy negyven szerzetes tartson szertartásokat. Érdekes, hogy az új Gandancemplen kolostor alapításakor a nyitószertartáson a régi város még élo,, negyven öreg szerzetese vett részt.

A három szerzetes emlékei alapján kirajzolódik az egykori város képe. Dalai láma szentélyról a szerzetesek nem tettek említést, bár a dalai láma nyilvánvalóan e szentélyben időzött 1906-ban, s a tíz év alatti és tizenéves szerzetestanoncoknak kevéssé volt bejárása a Sain noyon xan palotájába. A visszaemlékezésekból nem egyértelmú, hogy a Cogčin és a Golīn dacan egyazon főszentély két elnevezése-e, avagy létezett egy régi, tibeti stílusú szentély (Cogčin dugan), valamint egy újabb, kínai stílusú szentély (Golīn dacan). A megmaradt, Kozlov által készített fényképeken egyetlen, tibeti stílusú főszentély látszik. Úgy tûnik, hogy a Golīn dacan, a Barūn dacan és a Jün dacan nem iskolák voltak, hanem befolyásos szentélyek. A kolostorban az összes jelentős vallási ünnepet tartották (cam, xailen stb.), és a kolostor szerzeteseinek száma is jelzi, hogy a Sain noyonī xürē a legnagyobb kolostorok közé tartozott. Mivel a leírások személyes emlékek, előfordulnak nem egybecsengó adatok, mint például a nyomda léte.

60 A szentélyek egy része épült csak tibeti stílusban; a zöld cseréptetejű épületek, így a három említett szentély is a kínai építészet jegyeit viselte.

${ }^{61}$ A három interjú adatai eltéróek arról, hogy a körmeneteket, avagy a táncot tartották előbb.

62 Az újév 16. napja a mongol kalendárium szerint a tavaszhoz tartozik. 


\section{Közeli gyülekezetek, zarándokhelyek}

Egy-egy mongol kolostor környékén számos további történelmi vagy szent hely állhatott. ${ }^{63}$ Uyanga járásközponttól két kilométerre délre, a Xan Xögšinhegyen álló tízméteres magaslat, a Xarūlīn Šiwē owō régen őrhely volt, később zarándokhely lett ( gorō mörgöl).

1. Az Uš’xai/Ǔšai/Uwšxai/Uš axai alacsony, fehér, emberforma kő, ma is a település nyugati határában áll. ${ }^{64}$ Rinčen Jün Erētīn xural (Uš axai xīd) néven 822-es számon jelöli a helyszínt. ${ }^{65}$ Cerendorj̆ szerzetes szerint régen egy kis szentély állt az Uš’xainál, ahol örökmécses égett (mönx jul), és mindennap tartottak szertartást. Egyfajta Lusīn süm, azaz a hely gazdaszellemeinek állított szentély volt, ahol a fehér és fekete nāgākat (lus, tib. klu) és ezt az emberformájú követ tisztelték. Más források szerint a gyülekezethez a rombolás előtt húsz szerzetes tartozott. ${ }^{66} 1990$-ben új, apró faszentélyt emeltek a régi szentély alapjain; a kőre a helyiek szerzetesi ruhát adtak. A szentélyt köralakban bekerítették; mögötte áldozati kőhalom (owō), keleti részén kőalakzat áll. Ma nem tartanak szertartásokat, csupán a hívek járnak ide áldozatot bemutatni (mörgölīn süm), mint azt a szentélyben elhelyezett két, áldozati javakkal teli asztalka mutatja. A szentélytől északra, kissé távolabb hatalmas, kövekből kirakott régi emlékhely áll (xeregsür).

2. A Böröljūît gyülekezet (Böröljūî̄īn xural) a járásközponttól 30 kmre északnyugatra, a Börölȳüut forrásánál, a Jün Ulān nevú helyen állt. ${ }^{67}$ A gyülekezetet Rinčen Jün Erētīn xural néven, 821-es számon jelöli a Borilȳūd-folyónál, mely a Bōröljūüt-folyó nevének elírása.

\footnotetext{
A szent helyek részletes leírását lásd www.mongoliantemples.org.

4 É: $46^{\circ} 28.242^{\prime}, \mathrm{K}: 102^{\circ} 15.638^{\prime}, 2006$ m.

65 Rinčen - Maidar 1979.

66 A kolostortól északra a Sain noyon jasā tamgīn xašā baišin mögött a Mergen ūšxai (xöšōô) külön építménye állt. E kő titkos erővel bírt, s egy Punsal nevú nő ült mellette, aki beszélni tudott vele (Dājaw 2006: 183). A követ Xadan xošūi embernek vagy Fehér Uwsxainak (cagān Uwšxai) is nevezik. A követ a „Xangain angi” expedíció kutatta 1987-ben, amikor a földbe süllyedt követ kiásták és felállították (Ičinnorow et al. 2002: 276).

67 É: 46³6.069’', K: 102¹2.862’, magasság: 2069 m.
} 
A megye atlasza és több adatközlő szerint a 17. században Lamīn gegēn, Luwsandanjanǰancan (tib. blo-bzang bstan-'dzin rgyal-mtshan, 1639-1704) alapította a kolostort, melyet ezért Öwgön xīdnek is neveztek ('régi kolostor'). Cerendorj szerzetes szerint a kolostorrombolást megelőző időkben kevés szerzetes, főként ifjú tanoncok tartoztak a gyülekezethez, mely az orvostudomány és gyógyszergyártás (em tan) helye volt. G. Banjragč, az épülő Manba dacan szerzetese szerint a Börölȳütīn xural a Sain noyonī xürē ,gyógyszergyára” (emīn üildwer) volt. A régi kolostorból ma mindössze a faszerkezettel megerósített déli agyagfal két darab, mintegy 4 méteres része áll. Más falak és esetleges szentélyépületek romjai nem láthatók, csupán téglák és a felszín kiemelkedése utal egykori épületekre.

3. A Böröljūüt gyülekezettől északra, $2800 \mathrm{~m}$ magas hegyekben található a Xyatrūn gyógyvíz, azaz Xyatrūnī rašān, mely ma az Uyanga járással szomszédos Bat-Ölzī járáshoz tartozik. ${ }^{68}$ Maidar Xyatrūlīn rašān néven jelöli e szent helyet. ${ }^{69} \mathrm{~A}$ Xangai erdejéből kitúnő fehéres dombon gránitkövek között több meleg és hideg gyógyvizú forrás ered, melyek a Xyatrūn-folyót táplálják. A magas kéntartalmú folyó vize 26-36 fokos. A legenda szerint 1827-ben a filozófus Damcigdorj (gačin) meditált itt a 21 Tārā istennőn. A vizet azóta is gyógyvízként használják. A forrást Sain noyon xan, Namnansüren és hitvese is látogatták; állítólag itt látható jáspis kádjuk és lapos kőülésük. ${ }^{70}$

4. Rinčen említ egy gyülekezetet Barūn Erētīn xural néven, ${ }^{71}$ mely a Barūn Erēt vonulatnál, Uyanga járásközponttól mintegy 4 km-re délre helyezkedett el (É: 46²7.041', K: 102¹4.475', 2088 m). Cerendorj szerzetes szerint Barūn Erētben egyetlen szentély állt, és 20-30 szerzetes tartozott hozzá. 1937-ben lerombolták. Ma a kb. 60x60 méteres területet téglák és kövek borítják. Egy szentélyalap és talán sztúpák alapjai láthatók, s egy család él közelükben.

\footnotetext{
Ičinnorow et al. 2002: 323.

Maidar 1970: 88, No. 673.

70 Ičinnorow et al. 2002: 323.

71 Rinčen - Maidar 1979. No. 823.
} 
5. Szintén Uyanga területén, a járásközponttól északra, 30 km-re áll az egykori Olon süm ('sok szentély'), mely a legenda szerint Arslan kán városának romja a 12. századból. A kb. 150x200m területen hét épület alapzata vehető ki. ${ }^{72}$

\section{Írott források}

A kolostorról kevés kiadott forrás szól, azok is ellentmondóak. A tibeti nyelven, szerzetesek által írt krónikák adatai hitelesnek tekinthetők: Dharmatāla szerint a kolostornak összesen hat iskolája volt (dacan), és 3000 szerzetes tartozott hozzá. ${ }^{73} \mathrm{Az}$ Arany Krónika szerint ${ }^{74}$ a 2000 szerzetesnek otthont adó Sain noyonī xürēnek Serjē segédkönyvet (tib. se-rwa byes) követô filozófiai iskolája, ${ }^{75}$ illetve tantraiskolája is volt. E közlések egybecsengenek a szerzetesek emlékeivel.

Annyi bizonyos, hogy a kolostori hagyomány szerint az első szentély alapítása Lamīn gegēn első mongol megtestesülése, Luwsandanjanǰancan (tib. blo-bzang bstan-“dzin rgyal-mtshan, 1639-1704) alakjához köthető, aki az egyik leghíresebb 17. századi tudós, filozófus, csillagjós, orvos szerzetes volt. A mai Uyanga járás területén született, s itt alapította meg a Gandancemplen szentélyt, melyből a későbbi kolostor kifejlődöttt. ${ }^{76}$ Öwörxangai megye atlasza szerint a kolostor alapjait a xošŭt vezetô nemes zászlósúr, Šamba (xoš̄u jaxiragč jasag noyon) és Luwsandanjanǰancan közösen fektették le 1666-ban. ${ }^{77}$ Lamīn gegēn tovább költözött, és 1681-ben a közeli Barūn Erētben és Jün Erētben időzőtt. Még 1662-ben Börölȳütban alapított egy vallási iskolát (dacan), mellyel megteremtette az orvosi, csillagjósi és

\footnotetext{
Maidar 1970: 24. Ičinnorow et al. 2002: 275.

3 Lokesh Chandra - Bira 1977: 242-243.

74 Lokesh Chandra 1964. 162v.

75 A mongol kolostorok filozófiai iskolái három, tibeti eredetű segédkönyv nézeteire alapulhattak: Goman (tib. sgo-mang), Losallin (tib. blo-gsal-gling) és Serjē (tib. ser-byes). Sain noyon xan aimag területén ez utóbbi volt a legelterjedtebb. Bővebben lásd Teleki 2005.

76 Ičinnorow et al. 2002: 152-154. Lamīn gegēn megtestesüléseirôl lásd Dašbadrax 2004: 90100.

77 Ičinnorow et al. 2002: 226, 276, Cedendamba et al. 2009: 542.
} 
filozófiai tevékenység alapjait. ${ }^{78}$ Más forrás szerint 1662-ben Lamīn gegēn a Gandandašgenpellin (tib. dga'-ldan bkra-shis dge-'phel-gling) orvosi iskolát alapította a területen, valamint saját kolostorának alapjait is lefektette (a Lamīn gegēnī xürē a mai szomszédos Bayanxongor megye területén áll). ${ }^{79} \mathrm{~A}$ fenti ellentmondó adatok értelmezében segítségünkre lehet az a tény, hogy a hagyományos mongol életmód következtében egy szentély alapítása után az alapító és sokszor vele együtt az egész kolostor tovább vándorolt, jobbára kisebb gyülekezetet hagyva hátra. Böröljūitben lehetett az alapja a kolostornak, mely több helyen állomásozott (Jün erēt, Barūn erēt), mire letelepedett a mai Uyanga járásközpont medencéjében. Lamīn gegēn a sárgasüveges rend nézeteinek egyik legjelentősebb terjesztője volt a 17. században.

R. Banjragč levéltári kutatásai szerint 1919-ben elrendelték a mongol kolostorok történetének összeírását (örgöx ces), így mintegy hatvan kolostor története, köztük a Sain noyon xan kolostoráé is fennmaradt. ${ }^{80}$ Eszerint 1690 ben jasag wan Šamba idején Lamīn gegēn Luwsandanjanǰancan Guhyasamāja (Sandui, tib. gsang-'dus), Vajrabhairava (J̌igjid, tib. 'jigs-byed), Amitāyus (Ayūš, tib. tshe-dpag-med), Mahākāla (Maxgal, tib. mgon-po) és a több haragvó istenség tiszteletére két szentélyt és gazdasági egységet, gyülekezetet ( ̌as ) alapított, melyeket Gandanjančüwlinnek (tib. dga'-ldan byangchub-gling) és Gandanšaddüwlinnek (tib. dga'-ldan bshad-sgrub-gling) neveztek el. ${ }^{81}$ Öwörxangai megye atlasza szintén említi, ${ }^{82}$ hogy 1690-ben Luwsandanjanǰancan és jasag wan Šamba megalapította a Gandanjančüwlin dacant, valamint Guhyasamāja, Vajrabhairava, Amitāyus, Mahākāla és a többi haragvó tiszteletére szentélyt és gazdasági épületet emelt Gandanligšidlin dacan néven (tib. dga'-ldan legs-bshad-gling?). Banjragč szerint a város az 1720-as évektől indult fejlődésnek. 1724-ben jasag wan Dečinjaw idején Erdene bandida xutagt, Bančinbalbar (1703-1788 vagy 1705-1782,

\footnotetext{
Ičinnorow et al. 2002: 226-227.

79 Dašbadrax 2004: 96.

80 Banjragč 1998: 82-87. Banjragč másik múvében szintén szól a városról (Banjragč - Sainxū 2004; a cikk megírásakor e könyv a szerzőnek nem állt rendelkezésére).

81 Banjragč 1998: 84-86.

82 Ičinnorow et al. 2002: 226.
} 
a 2. Lamīn gegēn) Śrīdevī és Begce tiszteletére építtetett szentélyt, valamint a 2. Bogdtól (1724-1758) kapott kegytárgyakat és hangszereket. 1790-ben jasag wan Cedenjaw és toin bandid lam Dorjj̄igjid együtt alapították a tíz haragvó tiszteletére a Gandanǰambālin szentélyt (tib. dga'-ldan spyin-pa-gling ?). 1819-ben épült a filozófiai iskola, 1857-ben a csillagászati iskola, 1860ban az orvosi iskola. A megye atlasza erról így mesél: 1724-ben Bančinbalbar és jasag xošoi čin wan Dečinjaw Śrīdevī és Begce tiszteletére szentélyt és gazdasági hivatalt alapított, melyet Gandanšaddüwlin dacannak neveztek el. 1732-ben jasag xošoi čin wan Dečinǰaw és Bančinbalbar Śrīdevī tiszteletére és a cam tánc tiszteletére létrehozták a Gandanšagillin dacant (tib. dga'ldan ? gling). 1790-ben a Gandangimpillin dacan (tib. dga'-ldan dge-'phelgling), 1819-ben a Gandantegčinlen dacan (tib. dga'-ldan theg-chen-gling), 1835-ben a Gandandarjālin dacan (tib. dga'-ldan dar-rgyas-gling), 1840-ben a Gandanšaddüwdarjālin dacan (tib. dga'-ldan bshad-sgrub dar-rgyas-gling), 1860-ban a Gandanšangadarjālin dacan (tib. dga'-ldan ? dar-rgyas-gling) jött létre. A megyei atlasz nem jelöli forrását, s a két forrás adatai eltérôek. Egyetlen azonos időpont alapján az orvosi iskola a Gandandarjālinnal azonosítható. A megye atlasza azonos lapon Sain noyon xanī xošūnī xürē és Sain noyon xanī xošūn̄̄ xürēnī tūr' ('rom') néven két különböző helyet említ. Első a város szentélyeinek létrejöttét, második az 1937-es város szentélyeit írja le, ám a kettó érdekes módon nem cseng egybe. Ez szemlélteti, hogy napjaink kiadványai más kiadványok adatait másolják, sőt az is előfordul, hogy másik kolostor adatait közlik egy bizonyos név alatt. Noha az idős szerzetesek Gandan nevú szentélyekról nem beszéltek, mivel a szentélyek tibeti neveit nem tudták, elképzelhető, hogy azok a fenti neveket viselték. Néhány szentély rövid tibeti nevét a szerzetesek is említették, melyek a fenti leírásban szerepelnek (J̌ančüwlin, Gimpillin).

Banjragč leírása szerint a Sain noyonī xošū legfốbb kolostorának a mandzsu császár rendeletére az Ölzīg badrūlagč nevet ('szerencsét felvirágoztató,' tib. bkra-shis dar-rgyas-gling) és szerzeteseinek tüi tai ${ }^{83}$ pecsétes írást adtak. A 19. század elején a város a tibeti Kumbum és Tasilhunpo kolostorokkal

83 E kifejezés megfejtése további kutatásokat igényel. 
ápolt kapcsolatokat, s fóapátjai (gačin) tibeti mesterek voltak: Galsandanjanjamc (tib. bskal-bzang bstan- 'dzin rgya-mtsho), Luwsandamba (tib. blobzang dam-pa) és Galsan-Iš (tib. bskal-bzang ye-shes). ${ }^{84}$ 1896-ban Sain noyon xan Namnansüren apjától megörökölte a Bogdtól kapott, Begcét ábrázoló fő kegytárgyat, valamint a cam tánc rendezésének hagyományát. 1910ben a tíz haragvó képe, 15 kötetnyi szútra és egyéb kegytárgyak érkezését jegyezték fel. Ebben az idôben alapult a J̌üd tantrikus iskola, mely a Xačin gawlin nevet kapta. A városban az 1820-as évektől lehetett gawǰ filozófiai vizsgát (gawǰ̄n damǰā), az 1910-es évektől tantravizsgát tenni (agrambīn damǰā). A Bogd xan uralmának idejéről (1911-1921) nincs adat új szentélyról, szobrokról. A feljegyzés a kolostor közelében négy kis gyülekezetet említ: az Öndör gegēn Janabajar (1635-1723) által alapított, jóval északabbra fekvő Töwxön (tib. sgrub-khang) elvonulási helyet; az 1806-ban létrejött Bōrölǰüit gyülekezetet, ahol Lamīn čodow [tib. bla-ma('i) mchod-pa, Gurupūja, 'Áldozat a mesternek'], Naidan cogčid (tib. gnas-brtan tshogs-mchod, 'Áldozat az arhatoknak') és Manalīn čogo (tib. sman-bla'i cho-ga, 'Orvos buddha rituálé') szertartásokat tartottak; az 1856-ban, jasag wan Damčān korában J̌argalantban alapult gyülekezetet, ahol Mahākālát és Śrīdevīt tisztelték, valamint nyári elvonulást (xailen), Lamīn čodow, Naidan cogčid és más szertartásokat tartottak, illetve az 1723-1735 közötti időben a Lulān xan ūl-hegy előterében létrejött Gandandaščoilin szentélyt.

A történeti forrásokat áttekintve látható, hogy számos egyezés és számos különbség jelentkezik a szentélyek nevében, alapításuk idejében. Levéltári források fellelése, kutatása tisztázhatná ezen ellentmondásokat.

84 A hagyomány szerint a gačin lámákat a pancshen láma küldte a mongol területekre a Tasilhunpo kolostorból. A Sain noyonī xürē gačin lámáinak története további kutatásokat igényel. 


\section{A kolostor hírességei}

Minden kolostorban éltek híres szerzetesek. Sain noyon xan kolostorához több híres ember tartozott: Sodnompilīn Damdindorǰ gyermekkorától a Gandancemplen kolostorban tanult, majd a xailen nyári elvonulás idején a fővárosi Gandan kolostorban tett filozófiai vizsgát. T. Sangilxümbe volt (18861934) Sain noyon xan Xurdan cagān ('gyors fehér') vagy Samnā xar nevú híres írnoka, aki egy gyufa lángjának kialvása alatt három sornyi mongol írást tudott papírra vetni..$^{85}$

A város szerzetesei közül kiemelkedő Cerenǰawīn Yündendorǰ szerzetes (tibeti néven blo-bzang gyung-drung rdo-rje, 1871-1938), aki a mai Narīntēl járás területén született. Gyermekkorától Sain noyon xan kolostorában tanult, gaw̌, rawjamba, majd agramba fokozatot szerzett, és a mongol kolostorfóvárosban (Urga), majd Indiában, Tibetben vitázott jeles hittudósokkal. A vallásüldözés kezdetekor, 1930-ban Yündendorjot a Bayanjürxīn xürēbeli felkelésben való részvétellel gyanúsították, vagyonát elkobozták, és tíz év fegyházra, majd 1938 áprilisában golyó általi halálra ítélték. Az ítélethirdetéskor Yündendorǰ a félelem leghalványabb jele nélkül így szólt: „Adjatok egy kis idôt, imát mondok!”, majd csengő hangon felmondta a buddhista filozófiai ürességtermészetre vonatkozó tanítását. ${ }^{86}$

\section{A kolostor hagyományának felélesztése}

A 2007-es terepmunka során kiderült, hogy a kolostori hagyományt 1990-ben élesztették fel, amikor az egykori Nanslan dugan helyén (É: 46²7.912', K: $102^{\circ} 17.064$ ', magasság $2166 \mathrm{~m}$ ) új szentélyt emeltek, mely a Gandancemplen xīd nevet kapta. A felélesztők között volt Cedenǰančüw, Öljībadrax, BatTūl, Dondow, Dašjeweg és S. Tögs, aki ma a kolostor vezetóje (lowon lam). A megnyitón az egykori kolostor mintegy 40 szerzetese vett részt. A kolostor

85 Ičinnorow et al. 2002: 279.

86 Yündendorj̆ szerzetest 1992. december 21-én rehabilitálták. Emlékét tábla jelzi a felélesztett kolostorban. Ičinnorow et al. 2002: 370. 
1995. március 28-án került állami nyilvántartásba 1040707-es számon. A szentély a sárgasüveges rendhez tartozik, ma húsz szerzetese van. Mindennap tartanak Cogčin szertartást, ${ }^{87}$ valamint havi és éves szertartásokra is sor kerül: minden holdhónap 8. napján Ix Manal szertartást tartanak az Orvos Buddha tiszteletére, 15-én a Kandzsúrt (Ganjūr) és a kilenc drágakó porával festett Vajracchedikā szútrát olvassák (Yesön erden̄̄ Dorjjodow, tib. rdo-rje gcod-pa), a hónap 29. napján pedig Xangal szertartást tartanak a haragvó istenségek tiszteletére. Éves szertartásként a Buddhával kapcsolatos ünnepnapokat (Burxan bagš̄in düicen ödrüd), Kandzsúr, Gowīn lxā (tib. ' 'go-ba'i lha, személyes védőistenség) és Dar' exīn mandalšiwa (tib. maṇdala bzhi-ba, négyrétú mandalaáldozat Tārā istennőnek) szertartásokat tartanak. A kolostor oltárán Vajrapāṇi (Očirwān', tib. phyag-na rdo-rje) és Buddha ábrázolásai láthatók. A kolostor udvarán áll Sain noyon xan Namnansüren emlékoszlopa, melyet 1997 hatodik havának 8. napján Uyanga járás vezetője, D. Togōxü, a polgármesteri hivatal (Jasag dargīn Tamgīn gajar) és a Sain noyon xan Namnansüren Egyesület kezdeményezésére állítottak. A gránitoszlopra az alábbi mongol feliratot vésték: „Dzsingisz kán aranynemzedékének tagja, Mongólia első miniszterelnöke, Sain noyon xan, T. Namnansüren tiszteletére." A kolostor udvarán négy sztúpa áll, melyeket 1993-ban, 1994-ben, 1997-ben és 2000-ben emeltek. A 2004-ben állított sztúpát Yondonbat és Dašjeweg szerzetes emlékére, a 2000-ben állított sztúpát a felélesztett kolostor első apátja (xamba), Baldandorj emlékére emelték. A szentély előtt két imamalom áll.

Egy másik szentély, a Manba dacan (tib. sman-pa grwa-tshang) az egykori kolostor orvosi iskolájának helyén épült 2006. július 22. óta (É: 46²7.507', K: $\left.102^{\circ} 17.469^{\prime}\right)$ G. Banjragč szerzetes vezetésével. 2006 szeptemberében sztúpát emeltek udvarán. A gyülekezetet 12 szerzetesre tervezték, mindennapos Cogčin, havi és éves szertartásokkal. A kolostor újbóli felkeresése igazolná, hogy az elmúlt tíz évben hogyan fejlődött Uyanga járás vallási élete. A járás területén legális és illegális aranybányászat folyik, ezért a szerzetesek egyik fontos feladata, hogy szertartásokkal és áldozatokkal kiengeszteljék a helyszellemeket (lus sawdag, tib. klu sa-bdag, gzhi-bdag).

87 A szertartásokról részletesen lásd Majer 2008, Birtalan et al. 2015, www.mongoliantemples.org. 


\section{Zárszó}

A Sain noyonī xürē alapjait a 17. században fektették le, s a 20. század elejére Mongólia egyik legnépesebb kolostora lett. Népszerúségét a Sain noyon xanok jelenlétének, a terület gazdagságának, a vallási élet sokszínúségének köszönhette. A Sain noyon xanok egyrészt fenntartották a dzsingiszida láncolatot, másrészt jelentős politikai és gazdasági hatalmat birtokoltak, harmadrészt támogatták a buddhizmust. A Sain noyon xan palotájának leírása utal arra, milyen lehetett a négy halha kán rezidenciája. A kolostorban számos szentély és kolostoriskola állt, illetve a környéken további szentélyek voltak. A kolostor filozófiája a tibeti Szera kolostor segédkönyvét követte (megegyezik a Tasilhunpóban tanulmányozott segédkönnyvvel), mely egyébként is jellemző a Sain noyonī aimag területére. A kolostor fó jellegzetessége a tibeti gačin (tib. mkhan-chen) mesterek jelenléte, akik feltehetően a Tasilhunpo kolostorból jöttek, és többek között a filozófiai oktatásban segítették a szerzeteseket. A kolostornak volt újjászülető szerzetese is: Düwčin Sonom. Sor került tantrikus vizsgákra, mely kiemelkedő a mongol kolostorok világában. A 13. dalai láma látogatása szintén jelzi a kolostor jelentőségét, a Sain noyon xan népszerúségét, valamint a tibeti mesterek jelenlétét. A kolostor körül a szerzetesek nagy száma és a kolostor gazdagsága miatt kínai kereskedők is megtelepedtek. Noha a kolostor szentélyeinek nevét, alapítási dátumát a sok ellentmondó forrás miatt nehéz meghatározni, három szerzetes egybecsengő emléke idézi fel az 1930-as évek, azaz a kolostorrombolás előtti idôk pezsgő vallási életét. A kolostor néhány régi fényképe hozzáférhető, melyekből képet kapunk a kolostor épületeinek kinézetéról, elhelyezkedéséről. 1990ben a kolostor hagyományát - a többi jelentős mongol buddhista kolostor hagyományához hasonlóan - a még élő egykori szerzetesek felélesztették, s tanítványaik napjainkban is folytatják a buddhista gyakorlat fenntartását, a buddhizmus terjesztését. A kolostor története és felélesztése szemlélteti a mongol buddhizmus 17. század utáni fôbb eseményeit, a forrástípusok pedig a mongol kolostorok történetének feltárásához használható adatok minőségét és mennyiségét. 


\section{Elsődleges források}

Majer Zsuzsa - Teleki Krisztina, M. Menddawā szerzetessel készített interjúk. 2006-2009. Mongólia.

Majer Zsuzsa - Teleki Krisztina, C. Cerendorǰ szerzetessel készített interjú. 2007. Mongólia.

Majer Zsuzsa - Teleki Krisztina, Č. Jamiyānsenge szerzetessel készített interjú. 2007. Mongólia.

Teleki Krisztina, M. Menddawā szerzetessel készített interjú. 2011. Mongólia.

\section{Felhasznált másodlagos szakirodalom}

Badarči, S. - Dugarsüren, N. 2000. Bogd xān̄̄ am'dralīn on darāllīn towčōn [A Bogd xan életének rövid eseménytára]. Ulānbātar.

Banjragč, R. 1998. „Sain noyonī xürē, tünī xögǰlld T. Namnansürengīn xolbogdox ni [A Sain noyon kolostorvárosa, fejlődése, T. Namnansürennel való kapcsolata]." In: Bogd xānt mongol ulsīn anxn̄̄ yerönxī said Sain noyon xan Tögs-Očirīn Namnansüren. Gombosüren, C. - Dorjdagwa, T. (szerk.), Ulānbātar, 82-87.

Banjragč, Č. - Sainxūü, B. 2004. Mongol xürē xīdīn tǖx (emxtgel) [A mongol kolostorok története]. Ulānbātar.

Batbayar, C. - Gombosüren, D. 2009. Mongol ba Tüwd XX zūn̄̄ exn̄̄ xagast. XIII Dalai lam Tüdwenjamc Mongold jalarsan tüx [Mongólia és Tibet a 20. század elején. A 13. dalai láma mongóliai látogatása]. Ulānbātar.

Birtalan Ágnes - Majer Zsuzsa - Szilágyi Zsolt - Teleki Krisztina 2015. Buddhizmus a mai Mongóliában. Hagyományos mongol múveltség III. DVD. Budapest: Eötvös Loránd Tudományegyetem, Mongol és Belső-ázsiai Tanszék - Mongolisztikai Kutatóközpont. 
Cedendamba S. - Lonǰid J. - Ganbold, N. - Batdoř̌, Š. - Erdenebat, M. 2009. Mongolīn süm xīdīn tüxen towčōn [A mongol kolostorok története]. Ulānbātar.

Dājaw, B. 2006. Mongol uran barilgīn tīxx. Ded dewter [A mongol építészet története. Első kötet]. Ulānbātar.

Dašbadrax, D. 2004. Mongolīn xutagtūdīn namtrīn oillogo /XVII-XX zūn/ [Mongólia szentjeinek élete, 17-20. század]. Ulānbātar.

Gombosüren, C. - Dorj̃uagwa, T. 1998. Bogd xānt mongol ulsīn anxn̄̄ yerönxī said Sain noyon xan Tögs-Očirīn Namnansüren [Az autonóm Mongólia első miniszterelnöke: Sain noyon xan Tögs-Očirīn Namnansüren]. Ulānbātar.

Ičinnorow, S. - Osor, G. - Gendgē, D. - Bayarsaixan, B. - J̌argalsaixan, C. Ičinnorow, J. - Balǰinnyam, B. 2002. Öwörxangai aimag. Tailbar tol' [Öwörxangai megye. Enciklopédia]. Ulānbātar: Mönxīn üseg XXK.

Lokesh Chandra (ed.) 1964. The Golden Annals of Lamaism. Hor chos- 'byung of Blo bzang rta-mgrin. 'Dzam-gling byang phyogs chen-po hor-gyi rgyal-khams-kyi rtags-pa brjod-pa'i bstan-bcos chen-po dpyod-ldan mgu byed ngo-mtshar gser-gyi deb-ther zhes-bya-ba bzhugs-so. New Delhi: Śata-Pițaka Series. Vol. 34.

Lokesh Chandra (ed.) - Bira, Š. (transcription and preface) 1977. The History of Buddhism in Mongolia (Tibetan text in Roman transcription). Dharmatāla Dam chos rgya-mtsho. (Śata-Pițaka Series. Vol. 235.) New Delhi: Sharada Rani.

Lxam, P. - Yerōlt, J̌. 2011. Xürē xīdīn jayag [Kolostorok rendszabályzata]. Ulānbātar.

Maidar, D. 1970. Mongolīn xot tosgonī gurwan jurag [Három mongol településrajz]. Ulānbātar. 
Majer Zsuzsa 2009. A Comparative Study of the Ceremonial Practice in Present-day Mongolian Monasteries. (PhD értekezés, Eötvös Loránd Tudományegyetem, Budapest)

Majer Zsuzsa 2012a. „Delgeriin Choir. The Monastery of Zawa Lam Damdin in the Gobi." Zentralasiatische Studien 41: 7-42.

Majer Zsuzsa 2012b. „Töwkhön, the Retreat of Öndör Gegeen Zanabazar as a Pilgrimage Site.” The Silk Road 10: 107-116.

Majer Zsuzsa 2013. „Three Monasteries by the Ongi River.” Zentralasiatische Studien 42: 83-134.

Majer Zsuzsa - Teleki Krisztina 2014. Reviving the Cam Dance Tradition in Mongolia. A Cam tánc hagyományának felélesztése Mongóliában. Traditional Mongolian Culture II. Hagyományos mongol múveltség II. Budapest: Eötvös Loránd Tudományegyetem.

Rinčen Byamba - Maidar D. 1979. Mongol ard ulsīn ugsātn̄̄ sudlal, xeln̄̄ šinǰlelīn atlas [A Mongol Népköztársaság néprajzi és nyelvészeti atlasza]. Ulānbātar.

Teleki Krisztina 2005. „Mongólia kolostorai az Arany Krónika jegyzéke alapján.” In: Birtalan Ágnes (szerk.) Bolor-un Gerel. Kristályfény. Tanulmányok Kara György professzor 70. születésnapjának tiszteletére. Budapest: ELTE Belsó-ázsiai Tanszék, 773-790.

Teleki Krisztina 2012. Monasteries and Temples of Bogdiin Khüree. Ulānbātar.

Veit, Veronica 1990. Die vier Qane von Qalqa. Teil II: Biographien. Wiesbaden: Otto Harrassowitz. 


\section{Internetes hivatkozások}

http://www.mongolinternet.com/famous/SainNoyonHanNamnansuren.htm (2016.03.01.)

http://mongoliantemples.org/index.php/en/component/domm/2028?view=oldtempleen $(2016.04 .01$.)

Képek:

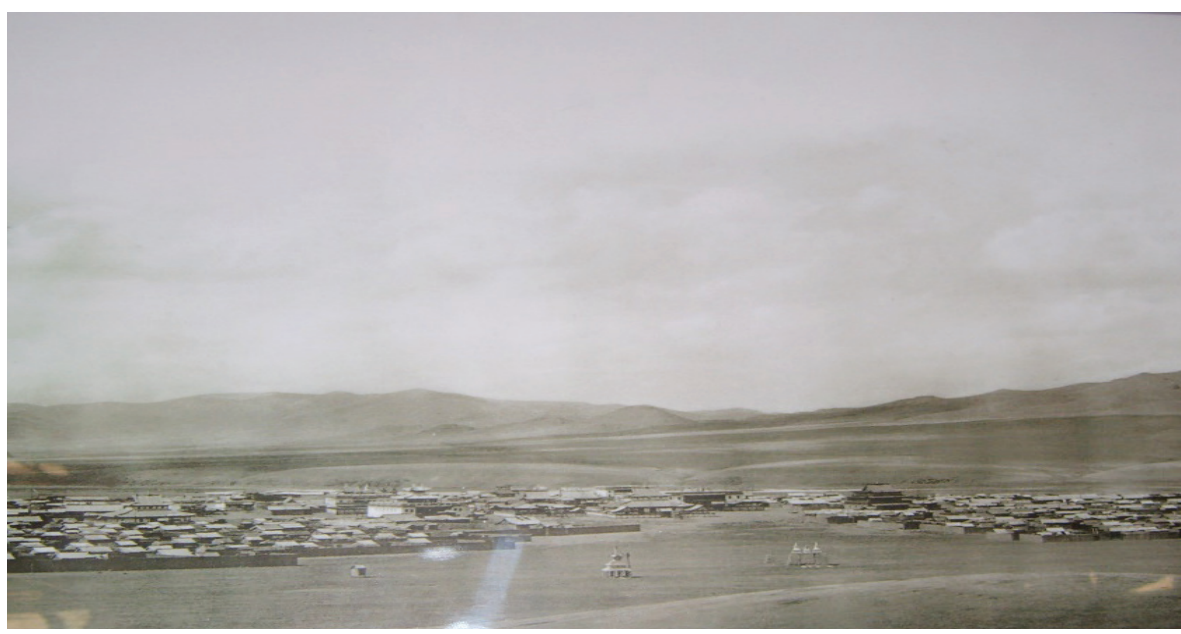

1. kép Sain noyon xan kolostora. P. K. Kozlov 1923-as felvétele a Gandancemplen kolostorban. Majer Zsuzsa és Teleki Krisztina felvétele az Arts Council of Mongolia kolostordokumentáló projekjének keretében. 2007. Mongólia, Öwörxangai megye, Uyanga járás. 


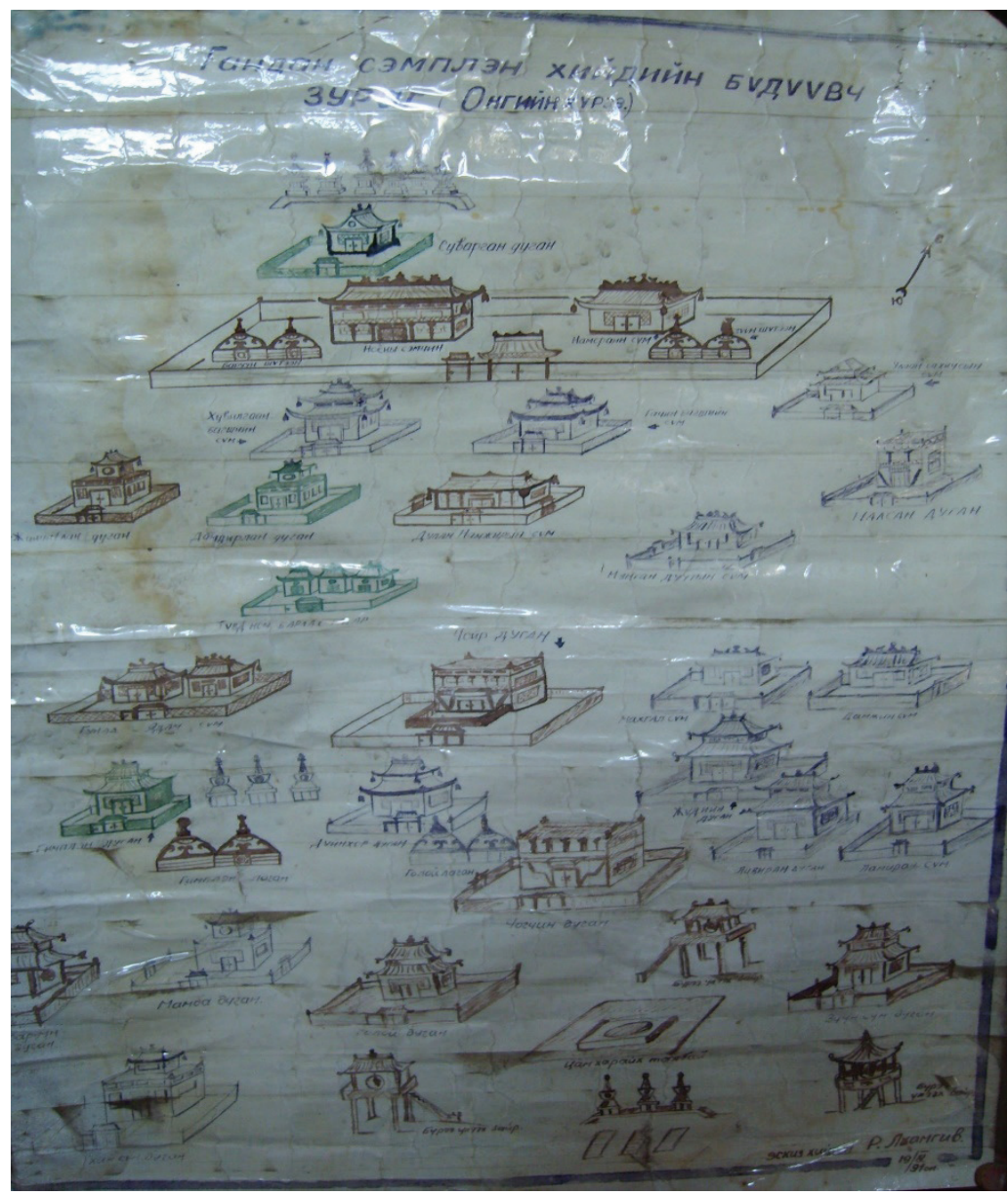

2. kép A kolostor szentélyeinek egykori elhelyezkedése. R. Lxangiw 1991-es rajza, melyet G. Banjragč óriz. Majer Zsuzsa és Teleki Krisztina felvétele az Arts Council of Mongolia kolostordokumentáló projekjének keretében. 2007. Mongólia, Öwörxangai megye, Uyanga járás. 


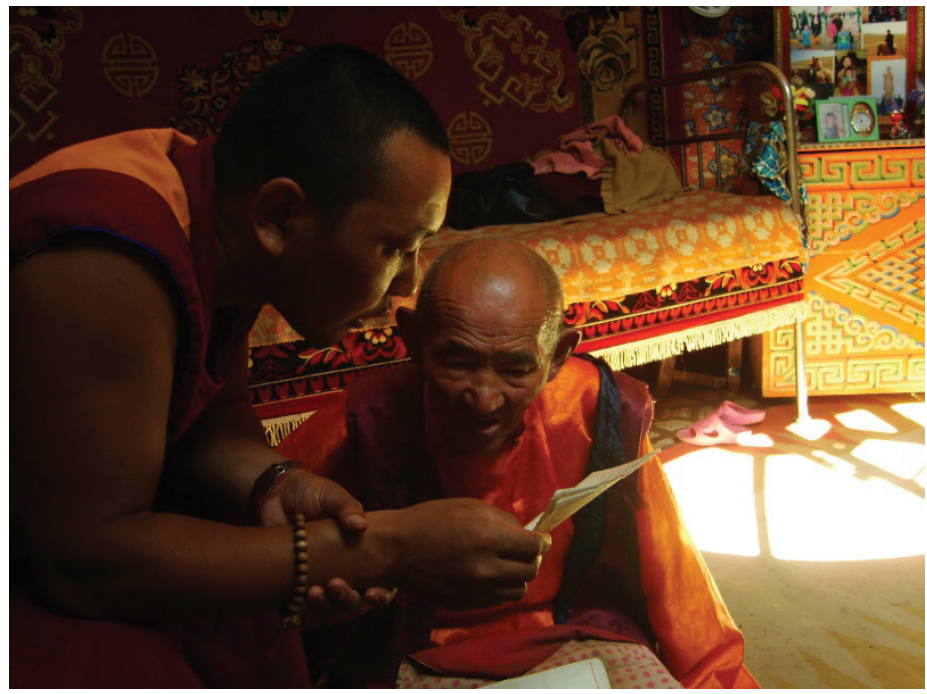

3. kép C. Cerendorǰ és O. Enxbayar szerzetesek. Teleki Krisztina felvétele az Arts Council of Mongolia kolostordokumentáló projekjének keretében. 2007. Mongólia,

Öwörxangai megye, Uyanga járás.

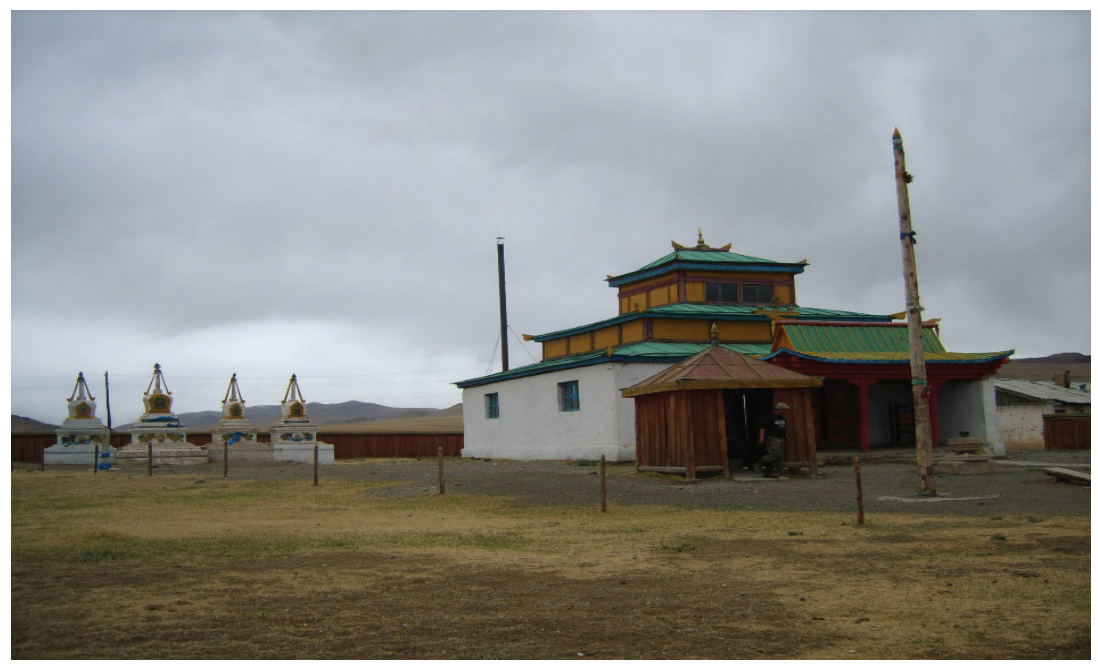

4. kép Gandancemplen kolostor. Majer Zsuzsa és Teleki Krisztina felvétele az Arts Council of Mongolia kolostordokumentáló projekjének keretében. 2007. Mongólia,

Öwörxangai megye, Uyanga járás. 